\title{
Cervical Mucinous Adenocarcinoma, Endocervical Type
}

National Cancer Institute

\section{Source}

National Cancer Institute. Cervical Mucinous Adenocarcinoma, Endocervical Type. NCI

Thesaurus. Code C40202.

A cervical mucinous adenocarcinoma characterized by the presence of malignant glandular cells that resemble those of the endocervix. 